\title{
A Young Porcellanite Occurrence from the Southwest Indian Ridge
}

\author{
GERHARD BOHRMANN, GERHARD KUHN, ANDREA ABELMANN, RAINER \\ GERSONDE and DIETER FÜTTERER
}

Alfred-Wegener-Institut für Polar- und Meeresforschung, Columbusstrasse, D-2850 Bremerhaven (F.R.G.)

(Received August 14, 1989; revision accepted January 12, 1990)

\begin{abstract}
Bohrmann, G., Kuhn, G., Abelmann, A., Gersonde, R. and Fütterer, D., 1990. A young porcellanite occurrence from the Southwest Indian Ridge. Mar. Geol., 92: 155-163.

A porcellanite layer, probably younger than $0.6-0.4 \mathrm{Ma}$, of a nearly monomineralic composition of opal-CT was sampled on the Southwest Indian Ridge during Polarstern cruise ANT-VI/3. The intense cementation of the rock, together with recent findings by the Ocean Drilling Program (Legs 113 and 120) and the occurrence of $a$ unique older porcellanite from Eltanin Core 47-15, provides evidence of very early silica precipitation in pure diatom oozes of the Southern Ocean. Such porcellanites occur in shallowly buried young sediments and provide a contrast to the established concepts of porcellanite formation.
\end{abstract}

\section{Introduction}

The evolutionary formation of chert occurs in two diagenetic stages, and is well documented in deep-sea sediments of various compositions. Biogenic silica (opal-A) dissolves in the sediments and crystallizes as opal-CT before it recrystallizes as fine-grained quartz, forming chert during progressive diagenesis (Heath, 1973; Wise and Weaver, 1974; Von Rad et al., 1978; Riech and Von Rad, 1979; Williams and Crerar, 1985). In this diagenetic maturation process, opal-CT (Jones and Segnit, 1971) forms an intermediate phase during the formation of quartz cherts. The solution of biogenic silica (opal-A) and reprecipitation of the intermediate silica phase (opal-CT) is well known from Tertiary, and to a lesser extent from Mesozoic sediments. In addition, the transformation from one to the other has been recorded in experiments (Kastner et al., 1977). Sediments which are predominantly composed of the silica phase opal-CT are termed porcellanites (Riech and Von Rad, 1979). These porcellanites occur in deeper sediments, and the transition from opal-A to opal-CT is mainly influenced by temperature, time and host-rock facies (Von Rad et al., 1978; Riech and Von Rad, 1979). Similar time and depth relationships are known from the Parcific Ocean (Hein et al., 1978) and from the Miocene Monterey Formation of California (Murata and Randall, 1975).

A Pliocene porcellanite recovered from 
Eltanin Core 47-15 (Weaver and Wise, 1973) on the Kerguelen Plateau $6 \mathrm{~m}$ below the seafloor (mbsf) provides a contrast to these established concepts of opal-CT precipitation. Because of its young age and shallow burial depth, the Core 47-15 occurrence was for a long time regarded as an exotic discovery. However, recent findings in the Antarctic realm by the Ocean Drilling Program (ODP) have shown that the Eltanin Core 47-15 porcellanite was not such an unusual discovery. During ODP Leg 113 a Pliocene porcellanite was recovered at ODP Site 689 on the Maud Rise at the top of the first core made (Barker et al., 1988). In addition, during ODP Leg 120 another young porcellanite occurrence was recorded at Site 751 at about 10 mbsf on the top of Kerguelen Plateau (Schlich et al., 1989), and only 75-80 km from Eltanin Core 47-15. All recently reported porcellanites occur in pure white diatom oozes and seem to be restricted to submarine plateaus in the Southern Ocean.

R.V. Polarstern (ANT-VI/3) recovered a porcellanite in Core PS1653-1 on the Southwest Indian Ridge near Bouvet Island (Kuhn, 1988). Whereas the three porcellanite occurrences mentioned above are Pliocene in age, the porcellanite from the Polarstern cruise is probably younger than $0.6-0.4 \mathrm{Ma}$. This porcellanite is of particular interest because it may be the youngest ever recovered from deep-sea sediments. In this letter, we present preliminary results of investigations on the porcellanite from Core PS1653-1 in the hope of contributing new ideas concerning the formation of deep-sea porcellanites, on sediments which are considered to be precursors of nodular and bedded cherts (Maliva and Siever, 1988).

\section{Geological setting and lithologies in PS1653-1}

Polarstern Core PS1653-1 was taken at $52^{\circ} 13.07^{\prime} \mathrm{S}, 9^{\circ} 30.37^{\prime} \mathrm{E}$ in $3209 \mathrm{~m}$ of water on the northwestern flank of the Shaka Ridge. This ridge is part of the Southwest Indian Mid-Ocean
Ridge which separates the Agulhas Basin from the Weddell/Enderby Basin. The core penetrated $7 \mathrm{~m}$ of sediment and is mainly composed of pure white ( $10 \mathrm{YR} 8 / 2,2.5 \mathrm{Y} 8 / 2)$ diatom ooze (Fig. 1) containing small amounts of silicoflagellates, radiolarians and foraminifera. According to quantitative XRD measurements, the opal content of the diatom oozes reaches 95 wt.\% of the dry bulk sediment. Two horizons of sandy diatom ooze ranging in colour from brown (10YR 5/3) through dark brown (10YR 4/3) to dark yellowish brown (10YR 3/4), partly with sandy diatom mud layers, are intercalated with the pure ooze (Fig. 1). These layers consist of 40-60 wt.\% of sand-sized constituents ( $>63 \mu \mathrm{m}$ ) with large amounts of various detrital components, mainly of volcanic origin (basaltic rock fragments, volcanic glass shards, etc.). Foraminifera are the major calcareous particles and their abundance is reflected by the carbonate content which varies from 0 to $16 \%$, and which remains relatively constant in the

\section{PS1653-1}

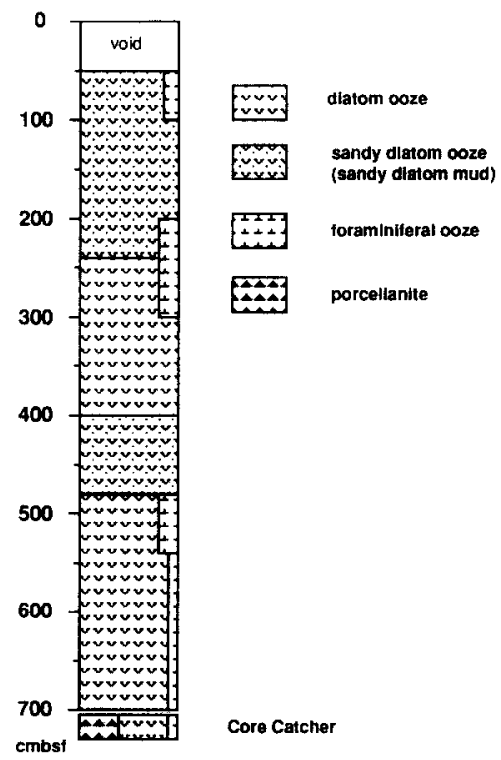

Fig. 1. Lithological column of Core PS1653-1 taken during Polarstern cruise ANT-VI $/ 3$ at $52^{\circ} 13^{\prime} \mathrm{S}, 9^{\circ} 30^{\prime} \mathrm{E}$ near the Southwest Indian Ridge. The porcellanite was recovered within the core catcher. $c m b s f=$ centimetres below seafloor. 
lowermost $1.5 \mathrm{~m}$ where values of $4-8 \%$ have been obtained (G. Ott, pers. commun., 1989).

\section{Description of the porcellanite}

A large porcellanite sample (Fig. 2) and several smaller fragments, which were created by damage that occurred during the penetration of the piston corer, were recovered from the core catcher. The largest porcellanite sample showed an irregular, rounded partly tubular shape, and its morphology is strongly reminiscent of silica concretions in the form of chert nodules or flint. Fracture surfaces were pure white, and appeared to be partly transparent, and a conchoidal fracture was evident in massively cemented parts of the rock. In contrast, more porous, less cemented sections which are intercalated as nests that become more porous from their rims towards their centres (Fig. 2), are pale white and reveal the brightness that is typical of porcellanite. Disseminated, light, white dots in the sample are caused by foraminiferal tests, whilst irregular black spots are small manganese ox- ide concretions, as revealed by EDAX-measurements under the scanning electron microscope. The surface of the silica concretion in contact with the host sediment (pure white diatom ooze) is characterized by a thin, light, white rim (Fig. 2) which is highly porous. The contact between the ooze and the strongly cemented rock appears to be sharp. This relationship seems to be typical of concretionary formations and has previously been described from Eltanin Core 47-15 (Weaver and Wise, 1973).

$\mathrm{X}$-ray diffraction analyses of the porcellanite show that, in addition to calcite, a monomineralic composition of opal-CT occurs (Fig. 3). Separate XRD runs from porous sections and strongly cemented parts show no significant differences in mineral composition. Based on measurements (LECO) undertaken on several samples, the carbonate content of the porcellanite ranges from 6 to $8 \%$. Using the (012) spacing of corundum $(d=3.479 \AA)$ as an internal standard we have calculated (101) $d$ spacing of opal-CT on three separate samples. Values of $4.11 \AA$ were found, which are typical of

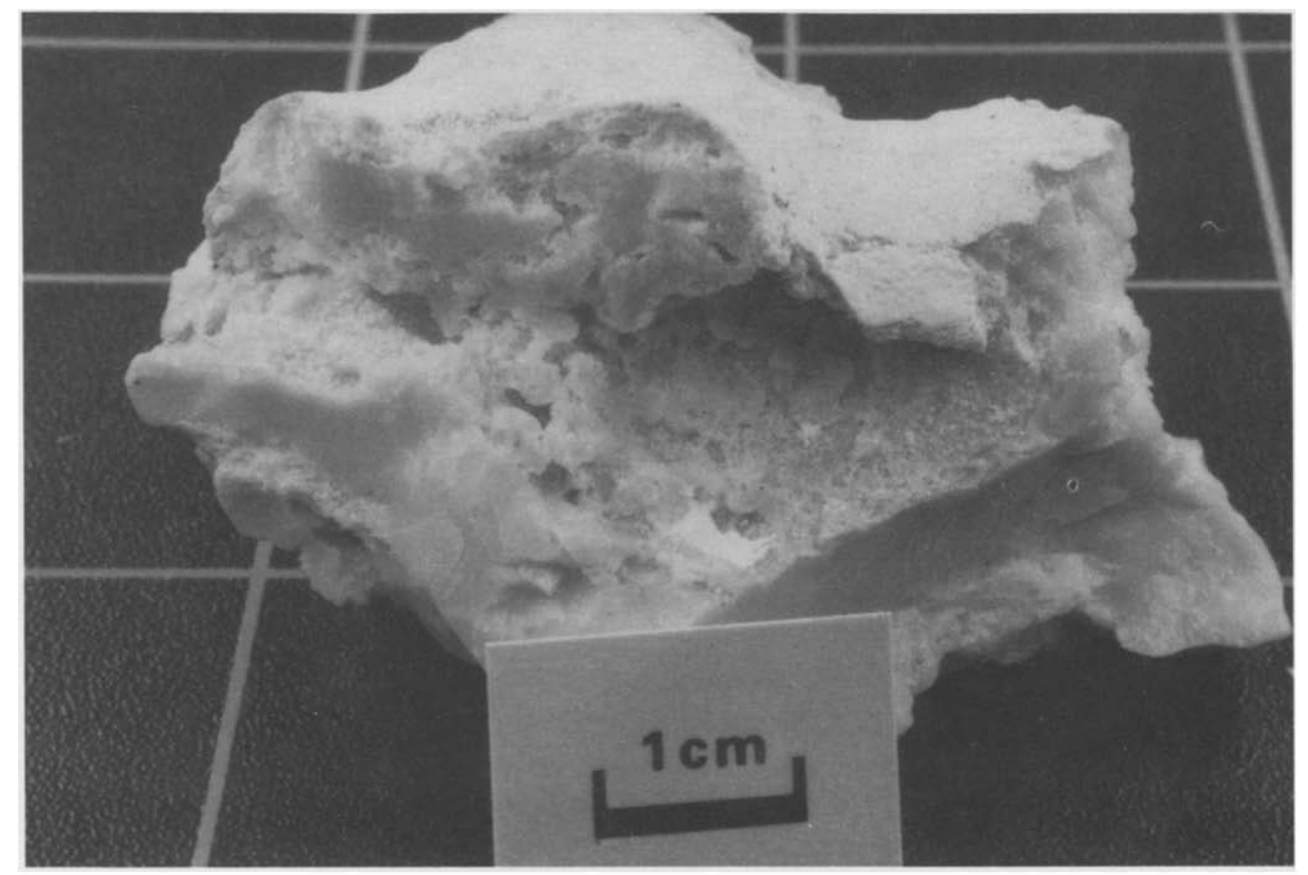

Fig. 2. Photograph of the large porcellanite fragment recovered from the core catcher of Core PS1653-1. 

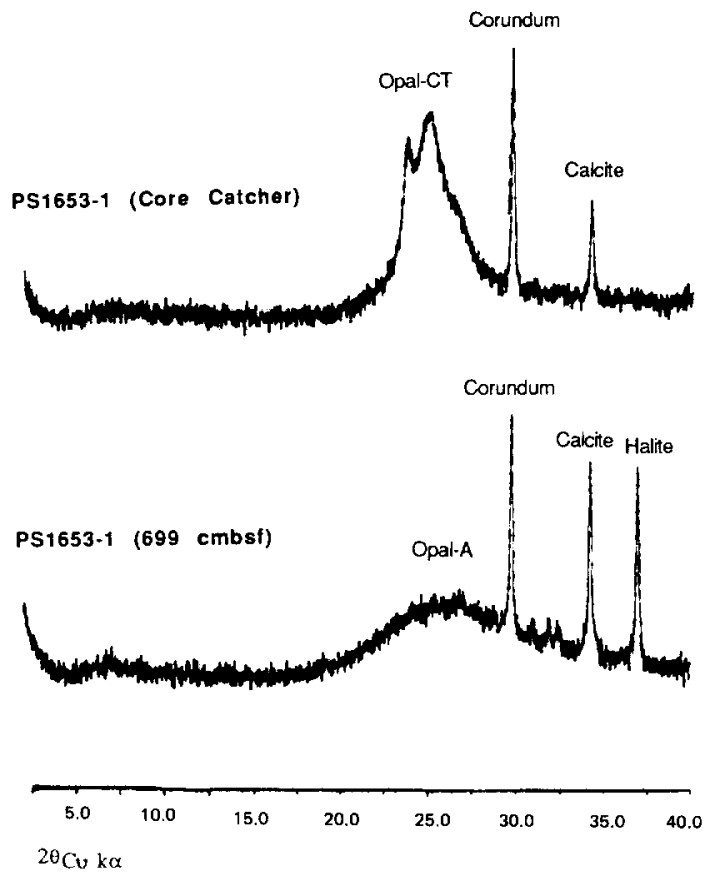

Fig. 3. X-ray records from the porcellanite of the core catcher of PS1653-1. For comparision, an X-ray diffractogram of a yellowish white diatom ooze which occurs just above in the core $(699 \mathrm{cmbsf})$ is shown.

poorly crystallized opal-CT, the crystallinity of which increases from a (101) $d$ spacing of 4.12 $\AA$ to typical values of $4.04 \AA$ in more mature deep-sea porcellanites and cherts that form during burial (Hein et al., 1978; Williams et al., $1985)$.

In the SEM studies of porcellanite we found opal-CT generally developed as thin $(0.1 \mu \mathrm{m})$ blades, with irregular ragged edges (Fig. 4C) forming lepispheres (Wise and Kelts, 1972) of variable size (Figs. 4A and 5A). Such lepispheres are well known from other occurrences, and are typically developed in opal-CT-rich sediments. The bladed structure of opal-CT, which shows tridymite-type twinning (Fig. 4F) (Flörke et al., 1975) is seen only on the surface of the lepispheres, where the opal-CT can grow into the remaining open pore space (Fig. 4D). Fractured sections of the lepispheres reveal that the inner structure is homogenous but shows also a higher degree of ultrastructural porosity (Fig. 4D). Based on microscopic observations, the largest opal-CT lepispheres are up to $40 \mu \mathrm{m}$ in size and occur in macroscopically porous nests in the rock (Fig. 4A). Foraminifera are clearly seen in thin sections as well as under the SEM (Figs. 5A-D). The tests seem to be totally embedded in massive opal-CT, and parts of the calcitic chamber walls show corrosion structure (Fig. 5B). In the porous parts of the rock, foraminifera often constitute sites for the growth of single opal-CT lepispheres. Carpets of lepispheres are also observed, as well as a total cover of foraminifera (Fig. 5A). Between the lepispheres significant amounts of heavily corroded and fragmented diatom valves were observed. The dominant species of diatom encountered between the lepispheres is Nitzschia kerguelensis (Figs. 4E, 5D and 5F).

\section{Age determination}

The age control on Core PS1653-1 is based on diatom and radiolarian biostratigraphic studies. The large numbers of Nitzschia kerguelensis (70-90\% of total diatom assemblages) throughout the entire core and the absence of significant amounts of Actinocyclus ingens places the core in the Thalassiosira lentiginosa Zone, which ranges through the last $0.6 \mathrm{Ma}$ (Gersonde and Burckle, in press). Rare occurrences of $A$. ingens in the lowermost part of the

Fig. 4. SEM photographs of the porcellanite of Core PS1653-1. A. A fracture section through the porcellanite shows various intensities of opal-CT cementation (scale bar $=100 \mu \mathrm{m}$ ). B. Large opal-CT lepispheres with diameters between 20 and 40 $\mu \mathrm{m}$ are well developed in the open pore space (scale bar $=10 \mu \mathrm{m}$ ). C. Lepispheres are composed of well developed blades of opal-CT showing typical irregular ragged edges (scale bar $=1 \mu \mathrm{m}$ ). D. The bladed structure is only developed at the surface of the lepispheres, a close inspection of fractured sections revealing the homogeneous ultrastructure and porous interior of the lepishere (scale bar $=5 \mu \mathrm{m}$ ). E. Between the opal-CT lepishperes, a corroded specimen of the diatom Nitzschia kerguelensis was often observed (scale bar $=10 \mu \mathrm{m}$ ). F. Opal-CT blades typically show tridymite-type twinning (scale bar $=5 \mu \mathrm{m}$ ). 


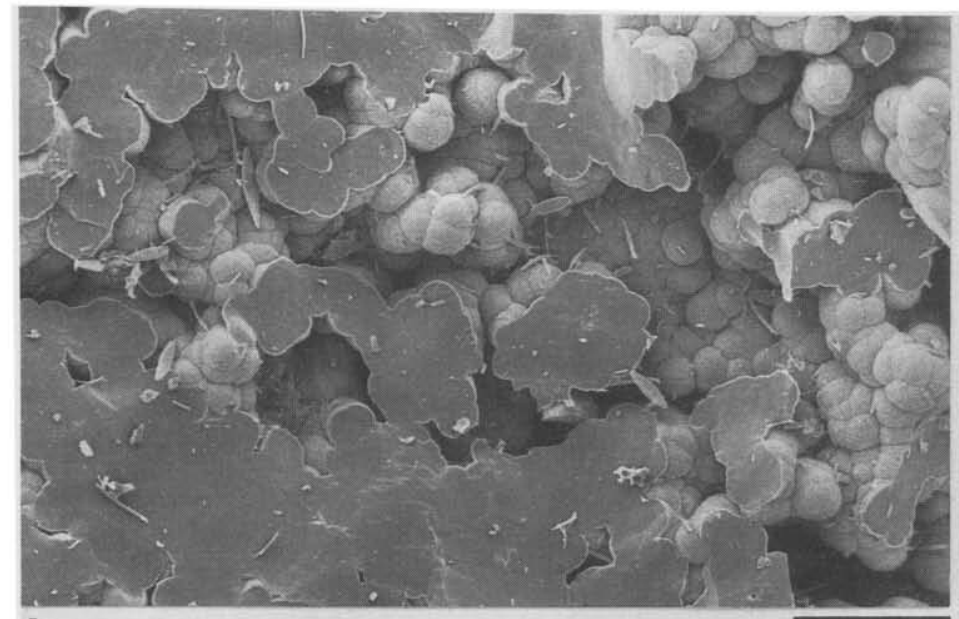

A

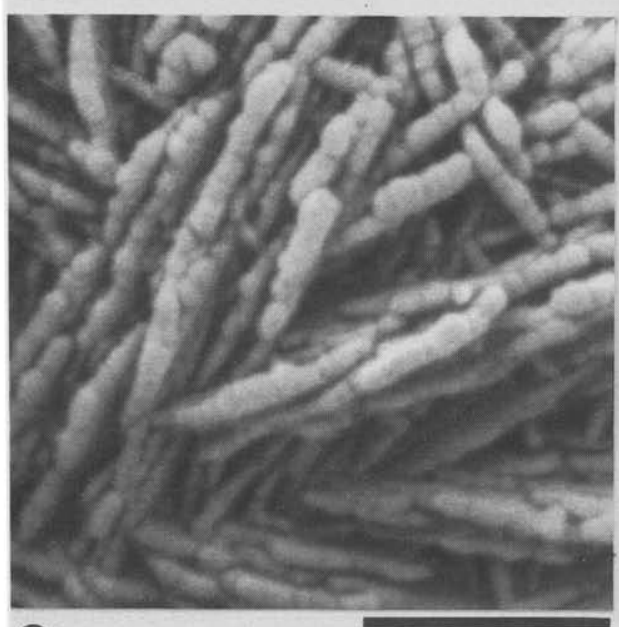

C

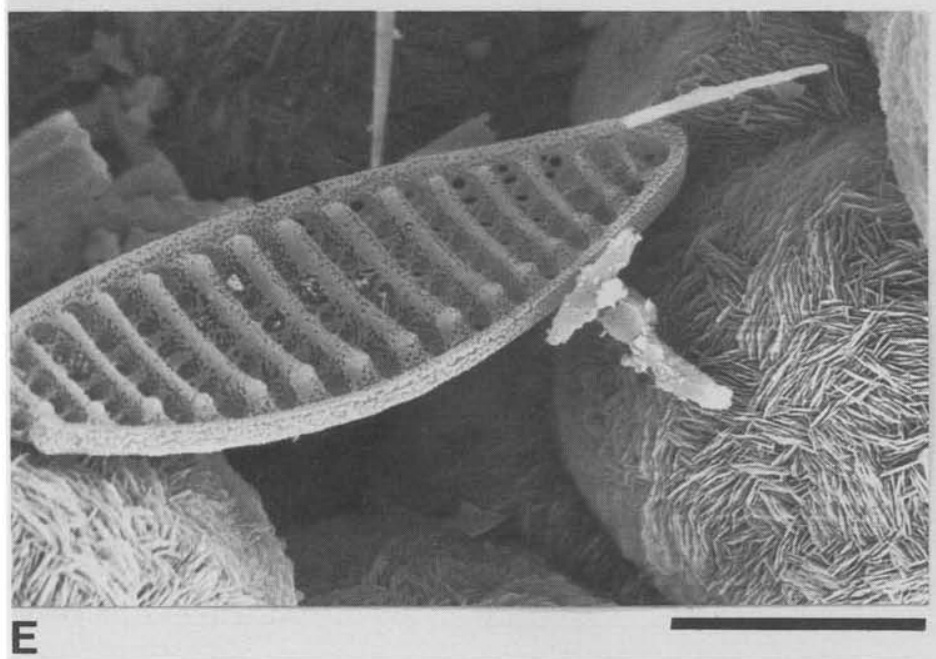

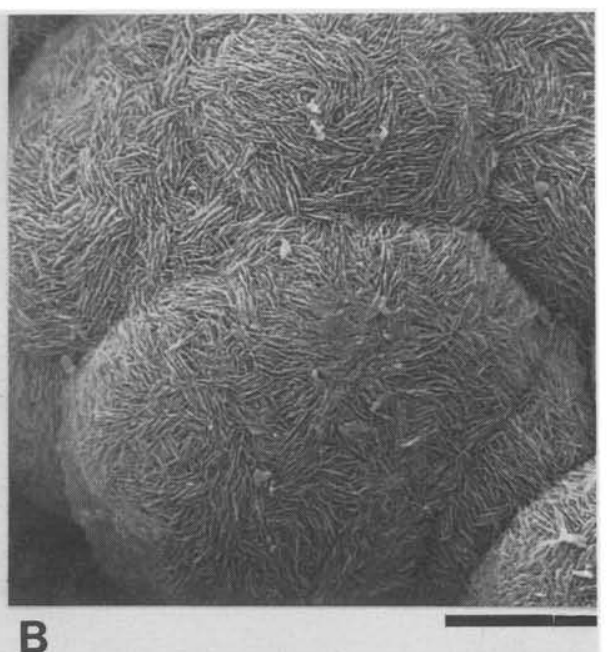

B

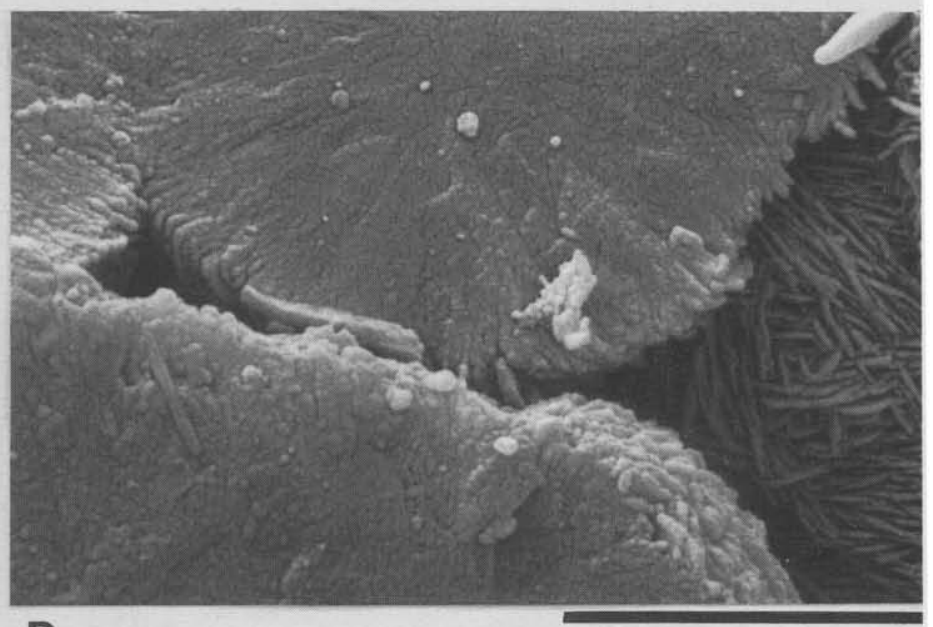

D

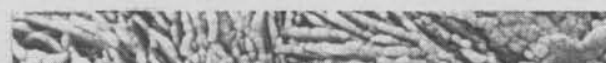

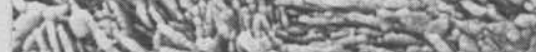
7. - 01025

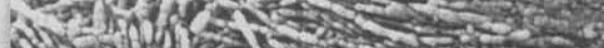

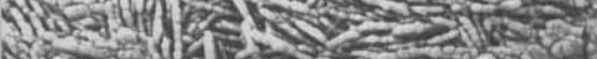

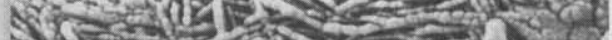

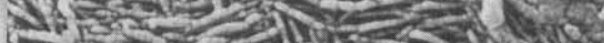
$-15=0$ IIVT Min $511 \mathrm{c}$ NMAN

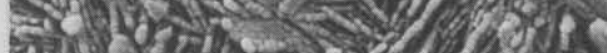

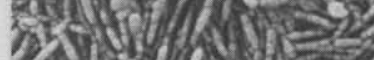
$F$ 

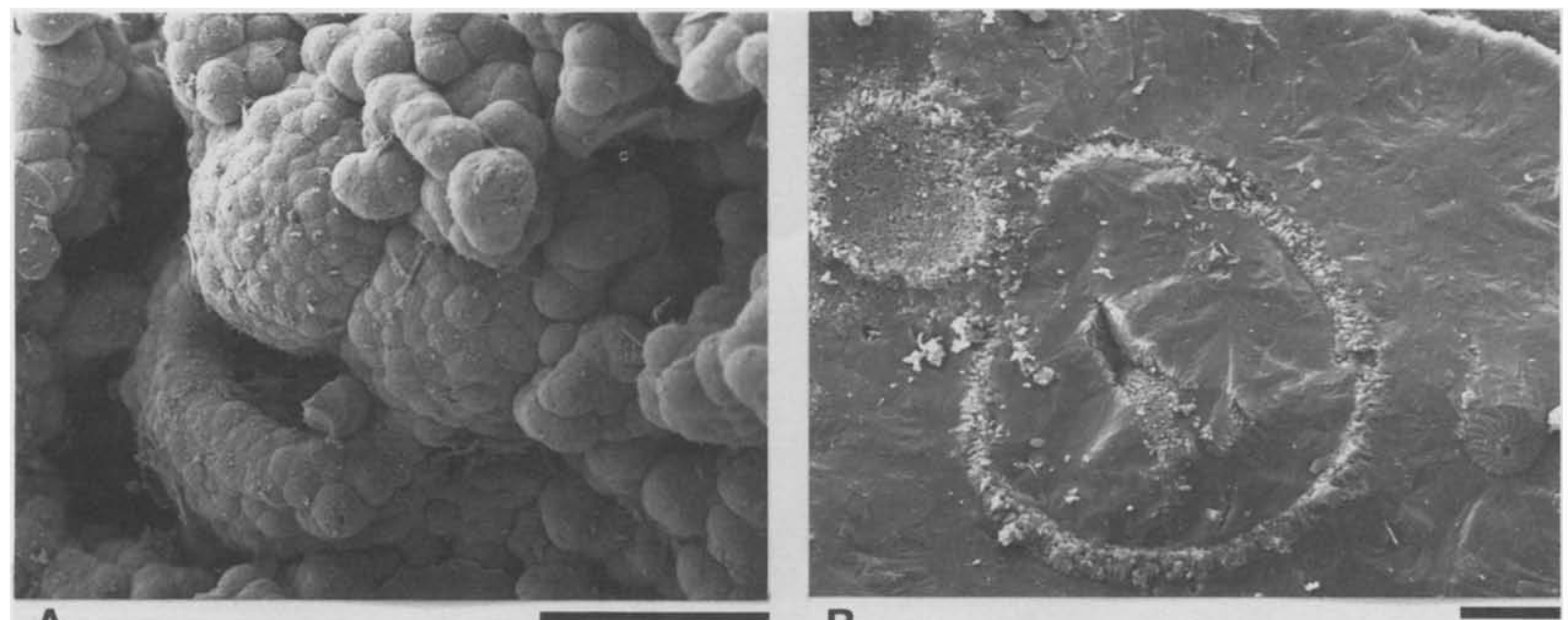

A

B
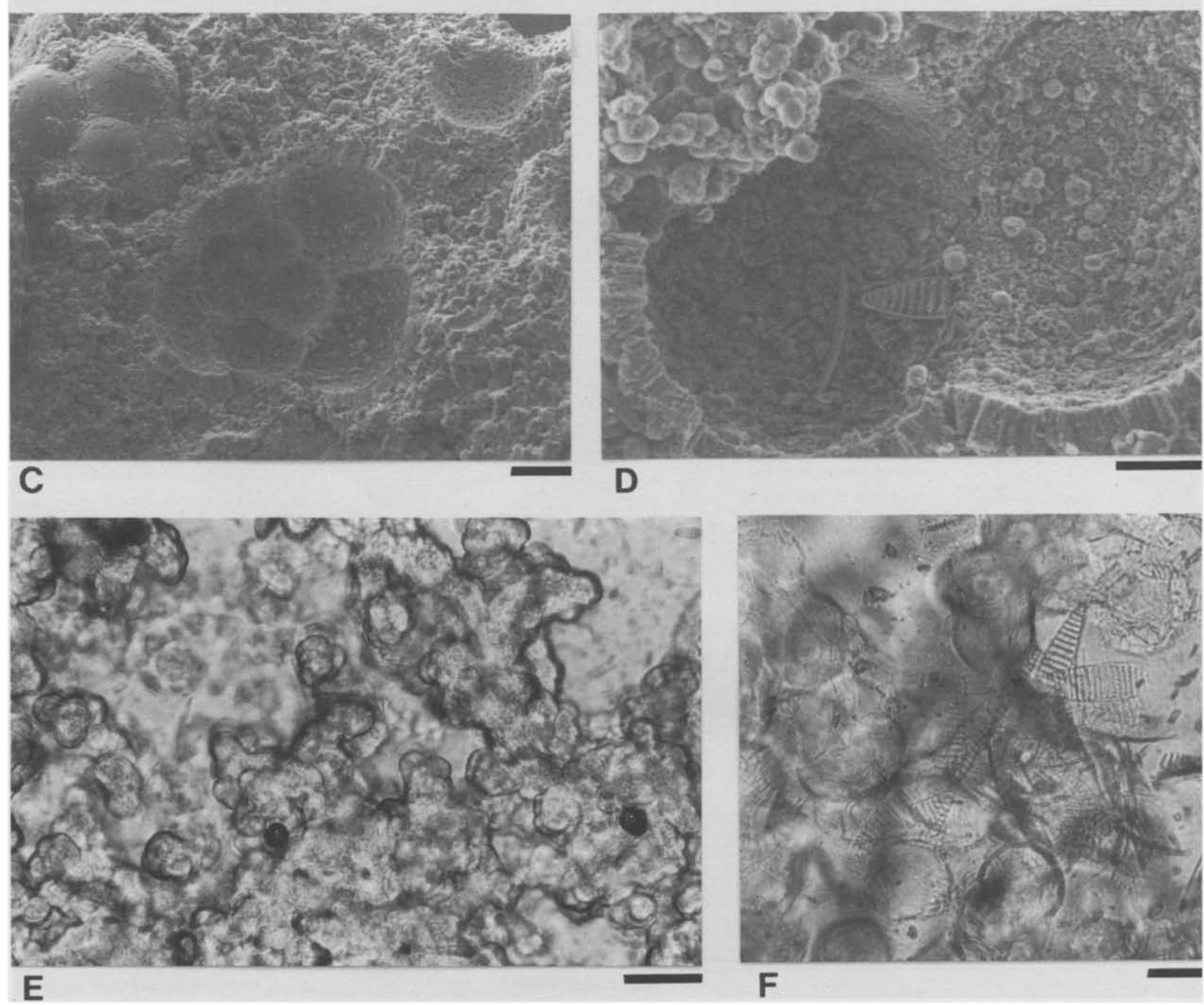
core (PS1653-1, $700 \mathrm{~cm}$ ) suggest a basal age near the boundary between the $T$. lentiginosa Zone and the underlying $A$. ingens Zone of about $0.6 \mathrm{Ma}$. However, a distinct decrease in diatom preservation, and a peak in the abundance of Eucampia balaustium, both of which occur close to the above-mentioned zonal boundary (Gersonde et al., in prep.), were not encountered in the lowermost part of the core. A basal age younger than ca. $0.4 \mathrm{Ma}$ is indicated by radiolarian studies. This places Core PS1653-1 in the Omega Zone of Hays and Opdyke (1967) because Stylatractus universus, which defines by its last appearance the base of the Omega Zone, was not encountered. The last appearance of Stylatractus universus was placed by Hays and Shackleton (1976) near the transition between isotope Stages 12 and 11 (around $0.42 \mathrm{Ma}$ ).

Based on these stratigraphic studies, the opalCT-cemented rock recovered in the core catcher can be assigned an age of younger than $0.6 \mathrm{Ma}$ or younger than $0.4 \mathrm{Ma}$. There are a number of indications that the opal-CT-cemented rock was found in continuous contact with the overlying diatomaceous sequences. Apart from the chemical silica precipitation, no contrast in the sedimentary facies can be determined. The carbonate content of the porcellanite ranges from 6 to $8 \%$, a value which is comparable to that in the overlying sediments. No significant change in the planktonic foraminiferal assemblage, was recorded from the lowermost sediment sample and the core catcher, nor from the foraminifera specimens which were filled with or embedded in opal-CT precipitate (Figs. 5A-5D). All foraminiferal assemblages are of Quaternary age (D. Spiegler, pers. commun., 1989). Nitzschia kerguelensis, which dominates the diatom assemblages throughout the entire core, also dominates the poorly preserved assemblages encountered in the porcellanite between the lepispheres (Figs. 4E, 5D and 5F).

\section{Discussion and conclusions}

The porcellanite occurrence in Polarstern Core PS1653-1 shows several similarities to that in Eltanin Core 47-15 (Wise et al. 1972; Weaver and Wise, 1973) with regard to its macroscopic and microscopic appearance and geological setting. Both porcellanites are strongly cemented rocks of nearly monomineralic opal-CT composition. They occur in relatively pure white diatom ooze and show sharp contacts with the host sediment. Some corroded diatoms are present in the pore spaces between the lepispheres, suggesting that the silica which forms the opal-CT was derived from the dissolution of the frustules. As already suggested by Wise and Weaver (1974) for Eltanin Core 47-15, silica from diatoms was reprecipitated as opal-CT following a dissolution phase. Compared to the biogenic ooze, the porosity is strongly reduced in the precipitation layer. Thus, the silica content is considerably more enhanced in the porcellanite, this content probably being attained, for example, by silica supply from a deeper level. Unfortunately, we cannot investigate this question because we were unable to sample sediments below the porcellanite.

The porcellanite of Polarstern Core PS16531 may be correlated with a strong seismic reflector at ca. $6-8 \mathrm{mbsf}$ in a $3.5 \mathrm{kHz}$ profile record at the core location. If this interpretation is correct, the porcellanite originates from a sil-

Fig. 5. SEM and thin section photographs from the porcellanite of Core PS1653-1. A. Foraminifera entirely encrusted with opal-CT lepispheres (scale bar $=100 \mu \mathrm{m}$ ). B. Foraminifera filled with opal-CT; calcite tests of the fossils show different stages of dissolution (scale bar $=10 \mu \mathrm{m}$ ). C. Foraminifera embedded in the opal-CT matrix (scale bar =30 $\mu \mathrm{m}$ ). D. Detail of a foraminifera within the opal-CT-cemented sediment (scale bar $=10 \mu \mathrm{m}$ ). E. Thin section micrograph of a porous section revealing the lepispheric nature (scale bar $=40 \mu \mathrm{m}$ ). F. In thin sections Nitzschia kerguelensis was often observed between the opal-CT lepispheres (scale bar $=20 \mu \mathrm{m}$ ). 
ica precipitation zone which represents a welldefined layer in the sedimentary sequence, this layer preventing further penetration by the gravity corer. Similar seismic observations were made on the Maud Rise in the eastern Weddell Sea at 5-18 mbsf (unpublished data), and a correlation was made with a silica precipitation zone drilled during Leg 113 (Barker et al., 1988). Such silica concretion layers are well known as bedded cherts in onshore outcrops and in older deep-sea sediments. At the location of Polarstern Core PS1653-1 a second strong reflector is partially developed at 10-12 mbsf parallel to the reflector at $6 \mathrm{mbsf}$ and probably represents a similar diagenetic horizon.

Hein et al. (1978), based on numerous data on Pacific porcellanite estimates the duration of burial and the burial depth (temperature) necessary for the initiation of the opal-A-opalCT transformation. Opal-CT precipitation takes place at relatively great burial depths $(>500 \mathrm{~m})$, within $10 \mathrm{Ma}$, and at moderate temperatures $\left(35^{\circ}-55^{\circ} \mathrm{C}\right)$. Transformation occurs rapidly at any depth where the temperature is high $\left(>55^{\circ} \mathrm{C}\right)$. At low temperatures $\left(<30^{\circ} \mathrm{C}\right)$, at shallow burial depths $(<300 \mathrm{~m})$, the conversion requires more than $30 \mathrm{Ma}$ (Hein et al., 1978). Estimates of such high temperatures are consistent with temperature determinations $\left(48^{\circ} \pm 8^{\circ} \mathrm{C}\right)$ from isotope measurements on opal-CT in the Miocene Monterey Formation (Murata et al., 1977). Similar depth and age distributions of opal-CT are reported from the Atlantic Ocean (Von Rad et al., 1978; Riech and Von Rad, 1979). Based on the results from Eltanin Core 47-15, Wise and Kelts (1972) excluded the time factor for the formation of porcellanites, and postulated that chemical precipitation of opal-CT could have occurred at any time in the sediments if favourable geological conditions existed; however, they do not distinctly negate a high-temperature factor. Weaver and Wise (1973) also speculated that porcellanite precipitation in Eltanin Core 4715 was influenced by local high heat flow, pos- sibly from an magmatic body. However, the existence of such an intrusive body was never demonstrated at the location of Core 47-15 on the Kerguelen Plateau. Because of its position on the active mid-ocean ridge, we cannot exclude a temperature influence on the formation of the porcellanite recovered in Polarstern Core PS1653-1 However, based on the $3.5 \mathrm{kHz}$ records showing a thick sediment sequence and no intrusive body, such a temperature influence does not seem likely. A transformation of opalA to opal-CT that is mainly temperature influenced (after Hein et al., $1989 ;>55^{\circ} \mathrm{C}$ ) may be excluded for the young porcellanite at ODP Site 689 , where in situ temperature measurements of between $4^{\circ}$ and $5^{\circ} \mathrm{C}$ have been made (Barker et al., 1988).

The porcellanite formation in the Pliocene sediments (Weaver and Wise, 1973; Barker et al., 1988; Schlich et al., 1989), and especially in the sediments younger than $0.6-0.4 \mathrm{Ma}$ as recorded in Polarstern Core PS1653-1, cannot be explained by the conventional concepts of opalA-opal-CT transformation. These porcellanites occur in pure diatom oozes, which seem to be restricted to the submarine plateaus and rises of the Southern Ocean around Antarctica. OpalCT precipitation may begin a relatively short time after the deposition of biogenic silica, and may not necessarily require a long geological time, as has been postulated generally for porcellanite formation (e.g. Hein et al., 1978); Riech and Von Rad, 1979). Until now, no definite cause have been found for such unusual porcellanite formation. Zijlstra (1987) postulated very early silica precipitation related to redox boundaries and bacterial metabolism in Cretaceous cherts and similar mechanisms controlling the chemical composition of pore fluids should be considered when detailed investigations of young porcellanite precipitation layers are carried out. However, studies can only be made if a complete sampling programme of undisturbed sediments and pore waters is undertaken. 


\section{Acknowledgements}

We thank W.U. Ehrmann and S.W. Wise for critical comments and discussion. The help of the technical staff, Captain Suhrmeyer and his crew during R.V. Polarstern cruise ANT-VI/3 is acknowledged. The English text was improved by M.J. Hambrey. We thank Rita Fröhlking, Helga Rhodes, Gabriele Ott and Wolfgang Morche for help in the laboratory work and for providing unpublished data. This paper represents contribution 268 of the Alfred Wegener Institute for Polar and Marine Research.

\section{References}

Barker, P.F., Kennett, J.P. et al., 1988. Proc. Ocean Drill. Program (College Station, Tex.) Init. Rep. 113.

Hays, J.D. and Opdyke, N.D., 1987. Antarctic radiolaria, magnetic reversals and climate change. Science, 158: 1001-1011.

Hays, J.D. and Shackleton, N.J., 1976. Globally synchronous extinction of the radiolarian Stylatractus universus. Geology, 4: 649-652.

Heath, G.R., 1973. Cherts from the eastern Pacific, Leg 16, Deep Sea Drilling Project. Init. Rep. Deep-Sea Drill. Proj., 16: 609-613.

Hein, J.R., Scholl, D.W., Barron, J.A., Jones, M.G., and Miller, J., 1978. Diagenesis of Late Cenozoic diatomaceous deposits and formation of the bottom simulating reflector in the Southern Bering Sea. Sedimentology, 25: 155-181.

Flörke, O.W., Jones, J.B. and Segnit, E.R., 1975. Opal-CT crystals. Neues Jahrb. Mineral. Monatsh., 8: 369-377.

Gersonde, R. and Burckle, 1.H. in press. Neogene diatom stratigraphy of Leg 113, Weddell Sea. In: P.F. Barker, J.P. Kennett et al., Proc. Ocean Drill. Program (College Station, Tex.). Init. Rep. 113.

Jones, J.H. and Segnit, E.R., 1971. Genesis of cristobalite and tridymite at low temperatures. J. Geol. Soc. Aust., 18: 419-422.

Kastner, M., Keene, J.B., and Gieskes, J.M., 1977. Diagen- esis of siliceous oozes I: Chemical controls on the rate of opal-A to opal-CT transformation - an experimental study. Geochim. Cosmochim. Acta, 41: 1041-1059.

Kuhn, G., 1988. Antarktische Konvergenz - Agulhas Becken. In: Fütterer (Editor), Die Expedition Antarktis-VI mit FS "Polarstern" 1987/1988. Ber. Polarforsch., 58: 123-124.

Maliva, R.G., and Siever, R., 1988. Pre-Cenozoic nodular cherts: Evidence for opal-CT precursors and direct quartz replacement. Am. J. Sci, 288: 798-809.

Murata, K.J. and Randall, R.G., 1975. Silica mineralogy and structure of the Monterey shale, Temblor Range, California. J. Res. U.S. Geol. Surv., 3: 567-572.

Murata, K.J., Friedman, I. and Gleason, J.D., 1977. Oxygen isotope relations between diagenetic silica minerals in the Monterey Shale, Temblor Range, California. Am. J. Sci. 277: 259-272.

Riech, V. and Von Rad, U., 1979. Silica diagenesis in the Atlantic Ocean: Diganetic potential and transformations. In: M. Talwani et al. (Editor), Deep Drilling Results in the Atlantic Ocean: Continental Margins and Paleoenvironments. (M. Ewing Ser., 3.) Am. Geophys. Union, Washington, pp. 315-340.

Schlich, R., Wise, S.W. et al., 1989. Proc. Ocean Drill. Program (College Station, Tex.). Init. Rep., 120.

Von Rad, U., Riech, V. and Rösch, H., 1978 Silica diagenesis in continental margin sediments off Northwestern Africa. Init. Rep. Deep-Sea Drill-Proj., 41: 879-905.

Weaver, F.M. and Wise, S.W., 1973. Early diagenesis of deep sea bedded chert. Antarc. J., Sep.-Oct.: 298-300.

Wise, S.W., and Kelts, K.R., 1972. Inferred diagenetic history of a weakly silicified deep sea chalk. Gulf Coast Assoc. Geol. Soc. Trans., 22: 177-203.

Wise, S.W., and Weaver, F.M., 1974. Chertification of oceanic sediments. In: K.J. Hsü, and H.C. Jenkyns (Editors ), Pelagic Sediments: On Land and Under the SEa. Spec. Publ. Int. Assoc. Sedimental., 1: 301-326.

Williams, L.A. and Crerar, D.A., 1985. Silica diagenesis, II. General mechanisms. J. Sediment Petrol., 55: 312-321.

Williams, L.A., Parks, G.A. and Crerar, D.A., 1985. Silica diagenesis, solubility controls. J. Sediment Petrol., 55: 301-311.

Zijlstra, H.J.P., 1987. Early diagenetic silica precipitation, in relation to redox boundaries and bacterial metabolism in Late Cretaceous chalk of the Maastrichtian type locality. Geol. Mijnbouw, 66: 343-355. 